\title{
TITLE:
}

\section{$<$ Review Article>Actual Status and Some Conservation Problems of Coastal Biodiversity in VietNam}

$\operatorname{AUTHOR}(\mathrm{S})$ :

THANH, DANG NGOC

\section{CITATION:}

THANH, DANG NGOC. <Review Article>Actual Status and Some Conservation Problems of Coastal Biodiversity in VietNam. Publications of the Seto Marine Biological Laboratory. Special Publication Series 2010, 10: 47-51

ISSUE DATE:

2010

URL:

http://hdl.handle.net/2433/144639

RIGHT: 


\title{
Review Article
}

\section{Actual Status and Some Conservation Problems of Coastal Biodiversity in VietNam}

\author{
DANG NGOC THANH
}

\author{
VietNam Academy of Science and Technology \\ 18, Hoang Quoc Viet Road, Cau Giay, HaNoi \\ Tel. (84-4) 8361778 Fax.( 84-4 ) 7564483 \\ E-mail: dnthanh@vast.ac.vn
}

\begin{abstract}
Vietnam is situated in the Southeast Asian monsoon region, with a long coastline of more than $3,200 \mathrm{~km}$. and a large continental shelf. The coastal area are occupied by a rich fauna and flora, a diversified landscape with typical coastal tropical ecosystems including: estuarine wetlands, mangrove forests, coral reefs, seagrass beds, coastal bays and lagoons. The mangrove forests in southern part of the country were seriously destroyed during the war. After the war, rapid socio- economic development in coastal zone, especially aquaculture, industrial and city construction, tourism had provided many negative influences on the coastal biodiversity : 1) Increasing of threatened wildlife 2) Degradation of coastal ecosystems 3) Decreasing of living resources in coastal waters. In response to this critical situation of the coastal biodiversity, many legal and technical measures were recently realized at national as well as in international level : Issues of different Laws related to Biodiversity Conservation, (Law of Fisheries, Law of Biodiversity), National Action Plan of Biodiversity, Participation in different activities related to World Biodiversity Strategy, Standardisation technical measures in fishing operations. A system of 15 Marine Protected Areas have been proposed to be established along the coastline, and some Marine Nature Reserves have already been recognized by UNESCO.
\end{abstract}

All the above mentioned activities show the efforts of VietNam to protect and develop coastal biodiversity, and actively participate in the World Biodiversity Strategy.

Key words: VietNam, coastal biodiversity, conservation problems

VietNam is situated in the Southeast Asian monsoon tropical zone of Western Pacific region, with a coastline more than $3,200 \mathrm{~km}$ and a large continental shelf. It has 2360 rivers with a major river mouth for every $20 \mathrm{~km}$ of coast, with large littoral estuarine areas, related to the Hong Ha River in the northern part and the Cuu Long (Mekong River) in the southern part of the territory. The central part is characterized by a system of bays and lagoons, and along the coast thousand of nearshore islands.

Monsoons are the characteristic feature of Vietnam climate, with a cold sea water in winter (November to February) in the north, while in the south, there is a typical tropical climate, with a steadier annual surface temperature, almost always above $25^{\circ} \mathrm{C}$.

All of these ecological conditions, provide for a diversified landscape with typical tropical ecosystems including as: mangrove forests, coral reefs, seagrass beds, estuarine wetlands, coastal bays and lagoons...occupied by a rich fauna and flora, these make up the characteristic biodiversity of the coastal area of Vietnam.

\section{Actual status of coastal biodiversity in Vietnam}

The coastal zones of Vietnam occupy large land area of about 6 million ha, nearly $20 \%$ of the 
whole surface of the country, with a population of about 21,4 millions $-26,7 \%$ of the total population of the country. After the war, the rapid socio-economic development led to many industrial, cultural activities in the coastal zone, affecting the coastal environmental conditions and biodiversity, and having serious ecological consequences.

\section{Increasing threat to coastal wildlife.}

The new Red List of Vietnam compiled in 2004 and published in 2007 showed a new situation of the biodiversity of the Vietnam coastal waters after 15 years, since the previous Red List compilation in 1992. The total number of threatened species as well as the threatened categories has remarkably increased in almost animal groups (Table 1). Some 53 species of marine fishes at the present time are threatened, of which 23 are in the Endangered IUCN category (EN), 3 in the Critically (CR) including Bostrichthys sinensis, Epinephelus undulatostriatus, Plectorhynchus gibbus) .Many species of coral reef fish are in the Endangered category, being overexploited for its original ornmental value.Among coastal marine invertebrates, 61 species have threatened status, in comparison with 40 species previously, of these 10 are in Endangered, and 6 species in Critically, including: Haliotis diversicolor, Trochus niloticus, Turbo marmoratus, Cyprae argus, Charonia tritonis, Nautilus pompilius. Three hard coral species are Endangered: Juncella gemmacea, Seriatopora hystrix, Stylophora pistilata, and 10 other hermatypic coral species have been labelled Vulnerable status. Remarkable situation were observed in the marine Reptilia and Sirenia groups. Among five species of marine turtles, 3 are in Endangered, including: Chelonia mydas. Lepidochelys olivacea, Erethmochelys imbricata, while 2 others Dermochelys coriacea, Caretta caretta as well as 1 species of Sirenia - Dugong dugon - are Critically. Especially, the crocodyl species Crocodylus porosus in the southern coastal zone at present time is Extinct in the wild (EW).

\section{Degradation of coastal ecosystems}

Along with the increasing threat to coastal wildlife, degradation was remarkable in the dynamics of coastal ecosystems during the last 10-15 years.

2.1 Estuarine wetland areas are reducing daily as a result of both natural and human factors. By consequence of building coastal dikes, artificial ponds for rice farming and shrimp aquaculture, destruction of mangrove forests after the war, at the rate of some thousands ha every year, wether in

Table 1. Increasing threatened status of coastal fauna and flora in Vietnam during period 1992 - 2007

\begin{tabular}{|c|c|c|c|c|c|c|c|c|c|c|}
\hline \multirow{2}{*}{$\begin{array}{l}\text { IUCN } \\
\text { Category } \\
\begin{array}{l}\text { Listed } \\
\text { groups }\end{array}\end{array}$} & \multicolumn{5}{|c|}{ Red List 1992} & \multicolumn{5}{|c|}{ Red List 2007} \\
\hline & $\begin{array}{l}\text { Total } \\
\text { listed } \\
\text { species }\end{array}$ & VU & EN & CR & EW & $\begin{array}{l}\text { Total } \\
\text { listed } \\
\text { species }\end{array}$ & $\mathrm{VU}$ & EN & CR & EW \\
\hline Mammals & 1 & - & 1 & - & - & 5 & 2 & 1 & 1 & - \\
\hline Birds & 5 & - & - & - & - & 2 & 1 & - & - & - \\
\hline Turtles & 4 & 1 & 3 & - & - & 5 & - & - & 5 & - \\
\hline Crocodiles & 1 & - & 1 & - & - & 1 & - & - & - & 1 \\
\hline Fishes & 37 & 5 & 3 & - & - & 53 & 23 & 21 & 3 & - \\
\hline Invertebrates & 40 & 12 & 7 & - & - & 61 & 42 & 10 & 6 & - \\
\hline Seaweed & 12 & 5 & - & - & - & 18 & 7 & 10 & 1 & - \\
\hline Total & 100 & 23 & 15 & 0 & 0 & 147 & 75 & 42 & 16 & 1 \\
\hline
\end{tabular}


some localities afforestation was successfully realized. Particularly, in Tram Chim wetland (province Dong Thap-southern Vietnam), had a great forest fire in 1995, destroying 305 ha of Melaleuca forests (arriere- mangrove). Consequently, red-headed cranes (Grus antigone), an IUCN migrant bird, has been remarkably reduced in number, from 1052 in 1989 to 302 in 1995 as a result of fire.

Negative ecological factors has seriously affected the biodiversity of wetlands areas. Migrant birds in the Xuan Thuy wetland (Red River Mouth) are permanently threatened and less frequently observed, because of daily habitat and food change.

2.2. Because of different reasons, mainly by overexploitation and pollution, coral reefs in coastal waters are in bad living conditions during the last 10 years. Only $1 \%$ of coral reefs have a high cover abundance index, meanwhile, low cover index make up more than $31 \%$. Average and good cover index reefs are $41 \%$ and $26 \%$ respectively. Generally, coastal coral reefs clearly decreased, and in some localities, cover index was strongly reduced to $30 \%$. Degradation of coastal coral reefs was found not only in corals, but also in the reef communities. Reef bentic fishes (Serranidae, Lutianidae and Pomacentridae), mollusks (Charonia, Trochus, Tridacna and Haliotis) were reduced in quantity. Conversely, the density of damaged animals for corals, such as starfish (Acanthaster planci), urchin (Diadema sp.) was increasing, sometimes to 100 ind./ha.

This demontrates that coastal coral reefs in Vietam are being threatened and degraded at the current time.

2.3. Seagrass beds are rather sensitive with changing environmental conditions in coastal waters. In all coastal waters, throughout the past 2 decades, seagrass beds have been reduced by an average of $50 \%$. In Quang Ninh province (Ha Coi bay), seagrass areas decreased from 1,200 ha in 1995 to 150 ha in $2003(87,5 \%)$. In Tam Giang, Cau Hai lagoons, the data shows 2,200ha and 100ha respectively $(54,5 \%)$. In Halong bay, before 1970, seagrass areas were well developed with 5 seagrass species, but at present have been seriously reduced or have entirely disappeared. Natural damage to seagrass beds cac be the result of seasonal decreases in water salinity, sedimentation and tropical typhoon. Human factors are aquaculture activities, water pollution and coas tal city construction.

\section{Threatened and damaged factors for coastal biodiversity in VietNam}

Coastal area with its rich fauna and flora, have occupied an important position in the socioeconomic development of the country. During the last 20 years, exploitation of coastal resources through: agriculture, fisheries, industry, tourism..have accelerated. Coastal fishing operations catch through $80 \%$ of total marine living products caught every year. Coastal aquaculture has rapidly developed $\mathrm{i}$, in response to the request to export more products. The most important tourism areas as Quang Ninh, Nha Trang, Vung Tau.. . are situated in coastal area. Many important industries as coal mining are or will be constructed in coastal zone. All this situation of the economical development of the country has provided many serious threats to coastal biodiversity.

1. The dramatic development of agriculture and aquaculture has remarkably reduced coastal area previously reserved as natural estuarine wetlands and mangrove forests in the Mekong delta. About 2,600 ha of mangrove area has been destroyed for construction of rice farming or shrimps ponds. As a consequence, mangrove, wetland biodiversity was seriously damaged and wil be difficult to restore.

2. The damaged fishing technics, such as dynamite and cyanide fishing, always have a negative influence on coastal biodiversity and living resources. The total catches in coastal waters has steadily increased, while fishing efficiency gradually decreased from 0,92 ton/ CV in 1990 to 0,34 ton/ CV in 2003. This clearly shows that overfishing has occured in this area. For some small pelagic and 
benthic targets, the catches occupied only $30-40 \%$, as compared with those before 1990 . The quantity of dugongs and green turtles has been reduced in Con Dao Island, related to the degradation of coral reefs and seagrass beds in this area.

3. Pollution is also an important factor affecting the biodiversity of coastal waters. High sediment discharges from coal mining activities in Quang Ninh province caused strong damage on coral reefs in Ha Long bay. Nutrient pollutants resulting from farming, cities along the seashore, has increased rapidly along the coastline, causing frequently eutrophication in coastal waters, and by consequence, intensive development of harmful algae, which are regularly occured in Ninh Thuan province of central Vietnam.

4. Along with human impact factors, natural factors typical of tropical climate regime are also important threat and damage factors for coastal biodiversity. On average, 35 tropical typhoons happen every year in the Bien Dong (South China Sea) which has strongly damaged coral reefs and seagrass beds in coastal waters. The restoration of damaged communities is very difficult andveryslowly progresses.I. Freshwater flows with sediment discharged from the coast decreasing salinity and increasing water turbidiry are considered as seasonal factor during the rainy season.

\section{Some actual problems of coastal biodiversity conservation in VietNam}

In response to the critical situation of the coastal biodiversity, many legal and technical measures to mitigate and prevent the biodiversity degradation were realised since the $1990 \mathrm{~s}$.

\section{Legal measures}

1. At the international level, Vietnam has approved the Convention of Biodiversity (1994), Ramsar Convention ( i994), CITES (1872) ; the Action Plan for Establishing a regional network of MPA in the S.EastAsian region (2012); Sustainable development of EastAsian Seas Strategy(2004); the Agreement to realize Millenium Objectives of Marine Biodiversity and Sustainable development of marine Fisheries, launched by FAO, and many others...

2. At the national level, the Vietam has signed the National Strategy for Estabblishment and management system of Protected Areas, in which 15 Marine PA are proposed to be established by 2020, and the Ministry of Fisheries is responsible office. In 2003, the Vietnam National Assembly has approved the Law of Fisheries, in which Article 9 is related to the Planning and Management of the Marine and Inland Protected Areas.

\section{Technical measures}

Within the framework of national and international Strategy and Action Plan for Protection and Sustainable development of marine biodiversity, many technical measures have been successfully realized at recently time in Vietnam.

1. Compilation and publication of the Vietnam Red List and Red Data Book in 1992- 1996 and in 2007.,using new IUCN Criteria and Categories. The Red List 2004 has listed 417 animal species and 524 plant species, considered as threatened species, with proposed protection measures for each one.

2. Following the issued Law of Fisheries, the Ministry of Fisheries has provided Regulations related to standardization of the exploitation seasons and dimensions of e fishing products, emphazing the prohibition of damaging fishing techniques, and others necessary measures to protect marine coastal biodiversity. In order to rehabilitate coastal fish resources, some national Programmes for reducing the fish exploitation in coastal waters, such as development the offshore exploitation and mariculture are being realized.

3. Within the framework of the UNEP GEF project "Reversing Environmental Degradation Trend in the South China Sea and the Gulf of Thailand", the Coral reefs National Action Plan for 2015 
has been established. A Programme to restore the Can Gio Mangrove forests near Ho Chi Minh City, that was seriously destroyed in thewar time, has been carried out successfully from 1978 .

4. Within the framework of the UNESCO MAB programme, started in 2000 year, some Marine Nature Reserve have been established and recognized by UNESCO, including Can Gio Mangrove forests, Xuan Thuy wetland, Cat Ba Island. With the sponsorship of GEF, DANIDA,and IUCN, some MPAs in Hon Mun, Cu Lao Cham, Con Dao and Cat Ba... have functional zoning and management.

All these above mentioned measures to protect and develop biodiversity, have had preliminary successes, and show the efforts of Vietnam to realize the National Action Plan for biodiversity, including coastal biodiversityVietnam also actively participate in the World Biodiversity Strategy. However, future development, must include close regional and international collaboration and assistance.

\section{REFERENCES}

1. Truong Thanh Tung. 2000. Distribution of mangrove forest in Can Gio Ho Chi Minh City. Proceedings of the Workshop "Management of sustainable use of natural resources environment coastal wetlands": 68.

2. Tran Van Doc \& al., 2000. Degeneration of Tram Chim National Park in Tam Nong Dong Thap province: current status and solutions. Proceedings Workshop" id.": p.78.

3. Nguyen Viet Cach, 2000 Biodiversity conservation and management in Ramsar site Giao Thuy District. Proc. Workshop " id. ": p.119.

4. Le Dinh Thuy, 2000 Birds Resources in Xuan Thuy National Park. I in "Mangrove Ecosystem in theRed River Delta" p.121. (in vietnamese)

5. Nguyen Van Tien. 2002. Seagrass beds in Vietnam sea. NXB KHKT \& al. HaNoi, 2002, 165p. (in vietnamese)

6. Do Cong Thung, 2004 Biodiversity Conservation $n$ the Coastal Zone M. Sarti of Vietnam. Proceedings Scien. Conf. HaiPhong 2004. ( in vietnamese)

7. Vo Si Tuan \& al., 2005. Coral Reefs of Vietnam. NXB KHKT Hanoi, 2005, 212 p. 